\title{
Bird species and abundances in fruit crops and implications for bird management
}

\author{
Melissa B. Hanney \\ Jason R. Boulanger \\ University of North Dakota, jason.boulanger@und.edu \\ Paul D. Curtis \\ Rachael A. Eaton \\ Benjamin C. Hawes
}

See next page for additional authors

How does access to this work benefit you? Let us know!

Follow this and additional works at: https://commons.und.edu/bio-fac

Part of the Agriculture Commons, and the Animal Sciences Commons

\section{Recommended Citation}

Melissa B. Hanney, Jason R. Boulanger, Paul D. Curtis, et al.. "Bird species and abundances in fruit crops and implications for bird management" (2019). Biology Faculty Publications. 33.

https://commons.und.edu/bio-fac/33

This Article is brought to you for free and open access by the Department of Biology at UND Scholarly Commons. It has been accepted for inclusion in Biology Faculty Publications by an authorized administrator of UND Scholarly Commons. For more information, please contact und.commons@library.und.edu. 


\section{Authors}

Melissa B. Hanney, Jason R. Boulanger, Paul D. Curtis, Rachael A. Eaton, Benjamin C. Hawes, Deanna K. Leigh, Cody A. Rossetti, Karen M. M. Sttensma, and Catherine A. Lindell 
Bird Species and Abundances in Fruit Crops and Implications for Bird Management

Melissa B. Hannay ${ }^{a, b,}{ }^{,}$, Jason R. Boulanger ${ }^{c}$, Paul D. Curtis ${ }^{d}$, Rachael A. Eaton ${ }^{e}$, Benjamin C. Hawes ${ }^{\dagger}$, Deanna K. Leigh ${ }^{g, 1}$, Cody A. Rossetti ${ }^{\mathrm{h}, 2}$, Karen M.M. Steensma ${ }^{\mathrm{h}}$, Catherine A. Lindell ${ }^{a, b, f}$

${ }^{\text {a }}$ Department of Integrative Biology, Michigan State University, 288 Farm Ln. Rm. 203, East Lansing, Ml 48824, USA

${ }^{\mathrm{b}}$ Ecology, Evolutionary Biology, and Behavior, Michigan State University, 103 Giltner Hall, 293 Farm Ln. Rm. 103, East Lansing, MI 48824, USA

${ }^{c}$ Department of Biology, University of North Dakota, 10 Cornell Street, Stop 9019, Grand Forks, ND 58202, USA

d Cornell University, 226 Mann Drive, Cornell University Ithaca, New York 14853, USA

e Department of BioSciences, Rice University, 6100 Main Street, MS 140, Houston, TX 77005, USA

f Center for Global Change and Earth Observations, Michigan State University, 1405 S. Harrison Rd., Manly Miles Building, East Lansing, MI 48823, USA

g Huxley College of the Environment, Western Washington University, 516 High St., Bellingham, WA 98225, USA

h Biology Department, Trinity Western University, 7600 Glover Rd, Langley, BC V2Y 1Y1, Canada

${ }^{*}$ Corresponding author. Department of Integrative Biology, Michigan State University, 288 Farm Ln. Rm. 203, East Lansing, MI 48824, USA. E-mail address: bradymel@msu.edu. 
${ }^{1}$ Present address: 1035 South Benton Dr, Sauk Rapids, MN 56379.

2Present address: 7701 Main St, Lino Lakes, MN 55038.

Declarations of interest: none. 


\section{Abstract}

Fruit consumption by birds is a costly problem in North America, yet basic information about the species and abundance of fruit-eating birds in fruit crops, and factors that influence abundance, are lacking. We conducted a study of fruit-eating birds in 'Honeycrisp' apples, blueberries, grapes, and sweet cherries in Michigan, New York, and the Pacific Northwest in 2012 and 2013. We documented the most frequently observed fruit-eating birds in each crop across our study regions, and used fruit-consumption data to identify bird species for each crop and region that have a great impact via fruit consumption. We found that American Robins (Turdus migratorius; hereafter, 'robins') and Cedar Waxwings (Bombycilla cedrorum; hereafter 'waxwings') are important fruit consumers across regions and crops, while House Finches (Haemorhous mexicanus), additionally, are important in the Pacific Northwest. We modelled and compared the abundance of fruit-eating birds in all four crops, and found that while abundance varied by region and crop, it was unaffected by heterogeneity in the surrounding land cover. Fruit growers can use information from this study to tailor bird management plans to specific crops and regions, depending on the species of concern. Keywords

Frugivorous birds; Crop Damage; Apples; Blueberries; Grapes; Cherries 1 Introduction

Birds are capable of causing extensive damage in a variety of crops, from fruit to grains (Johnson et al., 1989; Dolbeer et al., 1995; Linz et al., 2000; Lindell et al., 2016). Because they provide a concentrated and energy-rich food source, fruit crops are particularly vulnerable to consumption by birds. Losses caused by birds can have major economic impacts in North America; 'Honeycrisp' apple, blueberry, wine grape and sweet cherry 
growers in five major growing regions were estimated to suffer losses in the tens of millions of USD annually (Anderson et al., 2013).

Knowledge about the abundances and species of birds in particular regions and crops is necessary when mitigating bird damage (Luck et al., 2015). This type of information is still limited in North America (e.g., Eaton, 2016). Birds with diets that range from fully frugivorous to omnivorous consume fruit crops, including some species that are primarily insectivorous or granivorous (Boudreau, 1972). Species' fruit consumption can vary in magnitude; while robins and waxwings are both frequent visitors to fruit crops, waxwings consume fruit at a higher rate (Lindell et al., 2012a). Region- and crop-specific information can help to identify which species cause damage and indicate which bird management measures may be most effective, as species may exhibit different responses to management techniques. For example, scaring techniques such as air cannons or shooting may be less effective with sedentary territorial birds including many sparrow species, compared to highly mobile birds such as waxwings (Tracey et al., 2007; Rodewald, 2015). Recent advances in unmanned aircraft systems (known as drones) show promise as a bird management tool, but have been shown to be most effective against bird species with large body size, flocks, and birds outside of the breeding season (Mulero-Pázmány et al., 2017).

Fruit-eating bird abundance may vary regionally. Many crops are grown across distinct regions of North America; major grape producing operations exist in 13 different U.S. states from the East to West coasts (USDA 2016). Bird assemblages and abundances in fruit crops will vary by the growing region, just as bird species vary in presence and numbers throughout North America. For example, waxwings are voracious fruit consumers, but are far more common in the eastern U.S. than the west (Sauer et al., 2017); thus, their abundance in fruit crops may vary regionally.

Different crops vary in the type of food resource they provide to birds, and in the season and time frame that the resource is available. Fruit types of differing size and sugar content will attract different species. Small, sugar rich fruits such as blueberries and sweet cherries are 
attractive to species like waxwings, while larger, thicker-skinned fruits such as apples are attractive to large-billed birds such as American crows (Corvus brachyrhynchos, Tobin et al., 1989; Witmer and Soest, 1998).

Bird abundance may be influenced by the surrounding land-cover. While crops can provide food resources, agricultural fields often lack the structural complexity needed for nesting, perching and predator evasion that could be provided in adjacent, non-crop land-cover types (Guerrero et al., 2012). High levels of land-cover heterogeneity could provide a fine scale mixture of resources that would allow for higher numbers fruit-eating birds. Fruit-eating birds cross edges between forest and sweet cherry orchards more often than edges between nonforest and sweet cherry orchards, possibly because sweet cherries and forest provide complementary resources (Lindell et al., 2016).

Our study had multiple objectives. First, we documented the species and estimated the abundance of fruit-eating birds observed in 'Honeycrisp' apples (hereafter 'apples'), blueberries, grapes, and sweet cherries in our study regions in Michigan, New York, and the Pacific Northwest. Second, we combined data on species detections with observations of fruit-consumption behavior to determine which species are likely important fruit consumers in each crop and study region. Third, we examined factors that may influence the abundance of fruit-eating birds in our study crops: crop type, region and habitat heterogeneity. We expected that small, high-sugar fruits (e.g., sweet cherries, blueberries and grapes) would have both higher bird abundances and numbers of fruit-consuming species than apples, given that many different sizes of birds can access smaller fruits. We predicted that abundance estimates would vary by region, as our three different regions have different communities of birds. We predicted that higher habitat heterogeneity surrounding an orchard would lead to higher fruit-eating bird abundances, due to the existence of complementary resources in proximity.

\section{Methods}




\subsection{Study sites}

We conducted this study in 2012 and 2013 in multiple counties in Michigan, New York, Washington, and Oregon. In Michigan, sampling took place in Antrim, Allegan, Berrien, Benzie, Grand Traverse, Lake, Leelanau, and Van Buren counties. In New York, sampling took place in Cayuga, Cortland, Monroe, Niagara, Orleans, Oswego, Onondaga, Schulyer, Seneca, Tioga, Tompkins, Wayne, and Yates counties. In the Pacifc Northwest, we worked in Chelan, Douglas, Franklin, Okanogan, Skagit, Walla Walla, Whatcom, and Yakima counties in Washington and Umatilla county in Oregon. Study blocks were defined as contiguous areas of a single cultivar of a crop, delineated by different adjacent land-cover types that were at least 5 meters wide. The number of blocks sampled in each region and crop, are listed in Table 1. In Michigan apples, blueberries, grapes, and sweet cherries, study blocks had an average area of $1.2,1.5,0.9$, and 2.8 hectares, respectively. New York apples, blueberries, grapes and sweet cherries had average areas of $0.4,0.1,0.4$, and 0.5 hectares, while the Pacific Northwest had average areas of $3.1,3.8,1.2$, and 5.1 hectares, respectively. Some blocks had bird management measures in place. These included audio broadcast of predator and distress calls, hawk-shaped kites, inflatable tubemen, sucrose spray and/or netting, and nest boxes for American Kestrels (Falco sparverius) - a species that can deter fruit-eating birds (Shave et al., 2018). For a given crop, the percentage of blocks with bird management varied greatly each year. For example, $0 \%$ of sweet cherry blocks in the Pacific Northwest had bird management in place, while bird management was present in 93\% of grape blocks in Michigan in 2012.

Table 1 Number of study blocks in each crop and region in 2012 and 2013.

\begin{tabular}{lllllll}
\hline & Michigan & \multicolumn{3}{c}{ New York } & \multicolumn{2}{c}{ Pacific Northwest } \\
\hline \multirow{3}{*}{ Apples } & 12 & 13 & 12 & 13 & 12 & 13 \\
\cline { 2 - 7 } Blueberries & 17 & 11 & 15 & 8 & 22 & 7 \\
Grapes & 16 & 12 & 10 & 8 & 25 & 5 \\
Cherries & 14 & 7 & 17 & 11 & 25 & 8 \\
\hline
\end{tabular}




\subsection{Point counts}

We performed point counts from June to October in 2012 and 2013, prior to the harvest of each block, as close to harvest as possible. Point counts are a common and well-accepted way to estimate bird abundance (Ralph et al., 1995; Royle and Nichols, 2003). In most cases two observers conducted independent point counts at the same location, with no communication between them during or after the count (Nichols et al., 2000). Both observers recorded all birds visually detected within a 25-meter radius for 15 minutes. Only birds that were in the point count area where recorded; those flying over head were not used in the analysis. Each observer's point count was considered a separate temporal replicate. In most cases point counts for a site were performed before noon. Point counts were not conducted in rain or high winds. Point count locations were randomly chosen in each block surveyed, with both edge and interior points for blocks where interior points could be located at least 50 meters from any edge. Edge point locations were determined by first randomly choosing a direction (N, S, E, or W), representing which edge of the block to sample. A distance was randomly chosen along that edge to serve as the center of the point count. For interior points, we randomly chose a column and row from all interior rows of the block. Interior and edge points were considered temporal replicates. Previous work has suggested that bird damage in crops may be higher in agricultural field edges versus the interior in certain landscape contexts; this suggests that bird abundance may be higher on edges (Lindell et al., 2016). Our study design took this possibility into account by including edge and interior points in our study block. If results from edge and interior points were significantly different, we would not be able to use them as replicates within a block. To determine if this was the case, we included a covariate in our fruit-eating bird models signifying whether the point count was conducted in the edge or interior of a study block. In all crop models, the $95 \%$ confidence interval for this covariate included zero, indicating that edge vs. interior location was not significant in the models. 


\subsection{Bird observation data}

Foraging observations can be used to document consumption behaviour (e.g. Morrison et al., 2009). To document which bird species consumed fruit, foraging observations were conducted in Michigan, New York, and the Pacific Northwest in 2013 and 2014, at the same study blocks as the point counts. Foraging observations were not conducted on the same day as point counts, so as not to disturb the area before point counts were conducted. Foraging observations were conducted as close to harvest as possible, prior to the harvest. Most observations were made before noon. Using binoculars, the observer moved slowly through a one-acre area in the block, covering the entire acre within 30 minutes. When a bird was observed, the observer kept it in sight as long as possible to record how many fruits were consumed and where the fruit was taken (either the ground or the crop). For our analyses, we disregarded fruit taken from the ground, as well as observations under 20 seconds in durations. Fruit consumption behaviour was only used for species observed 2 or more times in a given crop/region combination. We considered a bird species to be a high consumer of fruit if an individual of that species was observed eating fruit during our observations, with regional data pooled to allow for species-level information.

\subsection{Classification of fruit-eating birds}

Bird species detected from the point counts were classified as 'fruit-eating' if the species met one of two criteria: if the species was seen eating fruit on at least two separate instances during our bird observations, or if the Birds of North America entry for the species described any fruit consumption in the diet section of the account (Rodewald, 2015).

By combining point count and observation data, we identified species in each crop and region as important fruit consumers. These species are likely to visit the crop frequently, and to have high fruit consumption rates. For each crop and region, if a species was among the top five most frequently observed species, and had a high fruit-consumption rate for that crop, it was designated as an important fruit consumer. 


\subsection{Land-cover data}

Surrounding land-cover types for each study block were visually interpreted using the National Agriculture Imagery Program (NAIP) land-cover layer (NAIP, 2013). Interpretations were verified by ground truthing (Lindell et al., 2016). Land-cover types were categorized for a 500-meter radius buffer around each study block, projecting from the centroid of the study block. A 500-meter radius was selected because it covers the breeding season territory sizes of many of the passerine birds we detected, and has been used to quantify the effect of landscape level features on bird abundance (Young, 1956; Mörtberg, 2001; Rodewald, 2015).

We categorized land-cover types as: developed land, bush fruit, tree fruit, vine fruit, other agricultural land, grassland, shrubland, forest, wetland, water, or barren. Land-cover heterogeneity was measured by edge density; calculating the amount of total 'edge' in the 500-m radius around the block (Fletcher et al., 2002; Saïd and Servanty, 2005). An edge was defined as any border between two different land-cover types. Landscapes with more edge will show more fine-grain mixing of different habitat types, and therefore increased heterogeneity.

\subsection{Data analysis and modelling}

Binomial mixture models can be used to estimate abundance when both site and temporal replicates are available; these models are hierarchical, and account for both abundance and observation processes (Royle, 2004; Kéry and Schaub, 2012). We constructed binomial mixture models for fruit-eating bird abundance for sweet cherries, blueberries, grapes and apples. There were multiple spatial replicates for each region, defined as the different study blocks. There were also, in most cases, temporal replicates for each study block. In cases where two observers were conducting independent point counts, the results were used as two temporal replicates. For some blocks, separate point counts were conducted in an edge vs interior area of the study block (as described above), in most cases on the same day or 
just a few days apart. These were also considered temporal replicates. Therefore, in cases where both edge and interior point counts were taken by two observers, there would be a total of four temporal replicates for a study block. These models were analysed in a Bayesian framework using the R2jags package (Su and Yajima, 2012).

The abundance model is as follows:

$N_{i, k} \sim \operatorname{Poisson}\left(\lambda_{i, k}\right)$

$\log \left(\lambda_{i, k}\right)=\alpha_{k}+\beta_{1} *\left(\right.$ Region $\left._{i}\right)+\beta_{2} *\left(\right.$ Heterogeneity $\left._{i}\right)+\mathrm{e}_{\mathrm{i}}$, where $e_{i} \sim \operatorname{Normal}\left(0, \sigma^{2}{ }_{\lambda}\right)$

The observation model is as follows: $\mathrm{y}_{i, j, k} / N_{i, k} \sim \operatorname{Binomial}\left(N_{i, k}, p_{i, j, k}\right)$

$\operatorname{logit}\left(p_{i, j, k}\right)=\beta_{k}+\delta_{i, j, k}$, where $\delta \sim \operatorname{Normal}\left(0, \sigma^{2}\right)$

Here, $k$ represents the number of years in the study (2), $j$ represents the number of temporal replicates (4 maximum), and $i$ represents the number of blocks. Count data are often overdispersed due to a high number of 'zero' counts. Overdispersion was accounted for in the abundance models by including a random variable for block $\left(e_{i}\right)$, and in the observation model through a random variable for each temporal replicate $\left(\delta_{i, j, k}\right)$. Covariates included in the models were region and edge density (our measure of land-cover heterogeneity). The two years when we collected point count data (2012 and 2013) were modelled with different intercepts $\left(\alpha_{1}\right.$ and $\left.\alpha_{2}\right)$.

We used uninformative priors for each model. Three Markov chains were run for 350,000 iterations, with the first 50,000 iterations being thrown out as 'burn in'. Model convergence was checked visually by looking at the mixing of the three Markov chains, and by ensuring that Rhat values for all models were within 0.1 of 1 , a range widely considered to be an acceptable range for convergence (Kéry, 2010). We assessed proper model fit using the ratio between simulated and actual data. A model can be considered a good 'fit' if this ratio is 
around one (Kéry and Schaub, 2012). Only models with a score of $1.00+/-0.02$ were included in the results. All models also had a Bayesian $p$ value within .02 of 0.5 ; values around 0.5 are considered ideal (Kéry and Schaub, 2012). A covariate effect was considered statistically significant if the $95 \%$ credible interval (CRI) for the posterior mean of the parameter for the covariate did not include zero (Kéry and Schaub, 2012). Four similar models were constructed to test the effectiveness of bird control, pooling all regions together. In these models, the only covariate was the presence of bird control.

\section{Results}

\subsection{Point Count Results}

A total of 255.5 hours of point counts were conducted, 92.75 hours in 2012 and 162.75 hours in 2013. In Michigan apples, blueberries, grapes, and sweet cherries, 16, 14.25, 11.5, and 30.75 hours of point counts were conducted, respectively. In New York we conducted $18,12,22$, and 19 hours of point counts in apples, blueberries, grapes and sweet cherries. Similarly, 22.5, 28.25, 19.5, and 31.5 hours were conducted in the Pacific Northwest. Eightyone bird species were observed during the point counts. Of these, $57(70.4 \%)$ were classified as fruit-eating species (Table 2).

The most frequently sighted species varied by growing region and crop (Table 3). Robins were the first or second most detected species in many of the crops across all regions. House finches were in the top five most frequently detected species in all Pacific Northwest crops. For apples, species that had a high consumption rate were house finches. For blueberries, Baltimore orioles (Icterus galbula), European starlings (Sturnus vulgaris; hereafter, 'starlings'), robins, house finches, waxwings, black-capped chickadees (Poecile atricapillus), American goldfinches (Spinus tristis) and white-crowned sparrows (Zonotrichia leucophrys) had high fruit consumption. For grapes, only robins and dark-eyed juncos (Junco hyemalis) were recorded consuming fruit. For sweet cherries, waxwings, Northern cardinals (Cardinalis cardinalis), house finches and robins had high fruit consumption rates. 
Important fruit consumers (Table 3) often varied by region and crop. We did not capture important fruit consumers in apples in New York and Michigan, as apple consumption behavior was not observed during observations. Robins were an important fruit consumer in blueberries and sweet cherries in all three regions. Grapes only had one important fruit consumer, and only in the Pacific Northwest: robins. House finches were important fruit consumers in every crop in the Pacific Northwest except grapes.

Table 2 List of all fruit-eating species observed during point counts.

\begin{tabular}{|c|c|c|c|}
\hline Common Name & Scientific Name & Common Name & Scientific Name \\
\hline American Crow & Corvus brachyrhynchos & Gray Catbird & Dumetella carolinensis \\
\hline American Goldfinch & Spinus tristis & Hairy Woodpecker & Picoides villosus \\
\hline American Robin & Turdus migratorius & House Finch & Haemorhous mexicanus \\
\hline Baltimore Oriole & Icterus galbula & House Sparrow & Passer domesticus \\
\hline Black-billed Magpie & Pica hudsonia & Indigo Bunting & Passerina cyanea \\
\hline $\begin{array}{l}\text { Black-capped } \\
\text { Chickadee }\end{array}$ & Poecile atricapillus & Lazuli Bunting & Passerina amoena \\
\hline $\begin{array}{l}\text { Black-headed } \\
\text { Grosbeak }\end{array}$ & $\begin{array}{l}\text { Pheucticus } \\
\text { melanocephalus }\end{array}$ & Northern Cardinal & Cardinalis cardinalis \\
\hline Blue Jay & Cyanocitta cristata & Northern Flicker & Colaptes auratus \\
\hline Brewer's Blackbird & Euphagus cyanocephalus & Northern Mockingbird & Mimus polyglottos \\
\hline Brown Thrasher & Toxostoma rufum & Orchard Oriole & Icterus spurius \\
\hline Bullock's Oriole & Icterus bullockii & Palm Warbler & Setophaga palmarum \\
\hline Cassin's Finch & Haemorhous cassinii & Pileated Woodpecker & Dryocopus pileatus \\
\hline Canada Goose & Branta canadensis & $\begin{array}{l}\text { Rose-breasted } \\
\text { Grosbeak }\end{array}$ & Pheucticus ludovicianus \\
\hline California Quail & Callipepla californica & $\begin{array}{l}\text { Red-bellied } \\
\text { Woodpecker }\end{array}$ & Melanerpes carolinus \\
\hline $\begin{array}{l}\text { Chestnut-backed } \\
\text { Chickadee }\end{array}$ & Poecile rufescens & $\begin{array}{l}\text { Red-headed } \\
\text { Woodpecker }\end{array}$ & Melanerpes erythrocephalus \\
\hline Cedar Waxwing & Bombycilla cedrorum & Savannah Sparrow & Passerculus sandwichensis \\
\hline Chipping Sparrow & Spizella passerina & Scarlet Tanager & Piranga olivacea \\
\hline Common Grackle & Quiscalus quiscula & Song Sparrow & Melospiza melodia \\
\hline Common Raven & Corvus corax & Spotted Towhee & Pipilo maculatus \\
\hline Dark-eyed Junco & Junco hyemalis & Summer Tanager & Piranga rubra \\
\hline Downy Woodpecker & Picoides pubescens & Tufted Titmouse & Baeolophus bicolor \\
\hline Eastern Bluebird & Sialia sialis & Vesper Sparrow & Pooecetes gramineus \\
\hline Eastern Kingbird & Tyrannus tyrannus & $\begin{array}{l}\text { White-crowned } \\
\text { Sparrow }\end{array}$ & Zonotrichia leucophrys \\
\hline Eastern Phoebe & Sayornis phoebe & Western Kingbird & Tyrannus verticalis \\
\hline Eastern Towhee & Pipilo erythrophthalmus & Western Tanager & Piranga ludoviciana \\
\hline European Starling & Sturnus vulgaris & Wild Turkey & Meleagris gallopavo \\
\hline $\begin{array}{l}\text { Great Crested } \\
\text { Flycatcher }\end{array}$ & Myiarchus crinitus & $\begin{array}{l}\text { Yellow-breasted } \\
\text { Sapsucker }\end{array}$ & Sphyrapicus varius \\
\hline $\begin{array}{l}\text { Golden-crowned } \\
\text { Kinglet }\end{array}$ & Regulus satrapa & Yellow Warbler & Setophaga petechia \\
\hline $\begin{array}{l}\text { Yellow-rumped } \\
\text { Warbler }\end{array}$ & Setophaga coronata & & \\
\hline
\end{tabular}

Table 3 The most frequently sighted fruit-eating bird species in each region for 2012 and 2013. 'Frequent species' are ranked by the number of birds detected per point count hour (denoted by 'Freq.'). 


\begin{tabular}{|c|c|c|c|c|c|c|c|c|}
\hline Region $^{\mathrm{a}}$ & Apple & Freq. & Blueberry & Freq. & Grape & Freq. & Sweet Cherry & Freq \\
\hline \multirow[t]{5}{*}{ MI } & $\begin{array}{l}\text { American } \\
\text { Goldfinch }\end{array}$ & 0.25 & $\begin{array}{l}\text { American } \\
\text { Robin }{ }^{b}\end{array}$ & 4.00 & $\begin{array}{l}\text { American } \\
\text { Crow }\end{array}$ & 0.17 & $\begin{array}{l}\text { American } \\
\text { Robin }\end{array}$ & 2.24 \\
\hline & Blue Jay & 0.13 & $\begin{array}{l}\text { Cedar } \\
\text { Waxwing }\end{array}$ & 0.77 & $\begin{array}{l}\text { Vesper } \\
\text { Sparrow }\end{array}$ & 0.17 & $\begin{array}{l}\text { European } \\
\text { Starling }\end{array}$ & 1.30 \\
\hline & $\begin{array}{l}\text { Eastern } \\
\text { Bluebird }\end{array}$ & 0.06 & $\begin{array}{l}\text { Chipping } \\
\text { Sparrow }\end{array}$ & 0.77 & $\begin{array}{l}\text { House } \\
\text { Finch }\end{array}$ & 0.09 & $\begin{array}{l}\text { Chipping } \\
\text { Sparrow }\end{array}$ & 0.42 \\
\hline & & & $\begin{array}{l}\text { American } \\
\text { Goldfinch }\end{array}$ & 0.63 & & & $\begin{array}{l}\text { Black-capped } \\
\text { Chickadee }\end{array}$ & 0.39 \\
\hline & & & $\begin{array}{l}\text { Song } \\
\text { Sparrow }\end{array}$ & 0.49 & & & $\begin{array}{l}\text { Common } \\
\text { Grackle }\end{array}$ & 0.36 \\
\hline \multirow[t]{5}{*}{ NY } & $\begin{array}{l}\text { Black- } \\
\text { capped } \\
\text { Chickadee }\end{array}$ & 0.37 & $\begin{array}{l}\text { American } \\
\text { Robin }\end{array}$ & 3.83 & $\begin{array}{l}\text { House } \\
\text { Sparrow }\end{array}$ & 0.39 & $\begin{array}{l}\text { American } \\
\text { Robin }\end{array}$ & 4.68 \\
\hline & $\begin{array}{l}\text { House } \\
\text { Sparrow }\end{array}$ & 0.37 & $\begin{array}{l}\text { Baltimore } \\
\text { Oriole }\end{array}$ & 1.58 & $\begin{array}{l}\text { American } \\
\text { Goldfinch }\end{array}$ & 0.28 & $\begin{array}{l}\text { Chipping } \\
\text { Sparrow }\end{array}$ & 1.52 \\
\hline & Blue Jay & 0.25 & $\begin{array}{l}\text { Song } \\
\text { Sparrow }\end{array}$ & 1.00 & $\begin{array}{l}\text { Eastern } \\
\text { Bluebird }\end{array}$ & 0.28 & $\begin{array}{l}\text { Cedar } \\
\text { Waxwing }\end{array}$ & 1.24 \\
\hline & $\begin{array}{l}\text { Palm } \\
\text { Warbler }\end{array}$ & 0.12 & $\begin{array}{l}\text { European } \\
\text { Starling }\end{array}$ & 0.50 & $\begin{array}{l}\text { Chipping } \\
\text { Sparrow }\end{array}$ & 0.23 & Gray Catbird & 1.13 \\
\hline & $\begin{array}{l}\text { American } \\
\text { Robin }\end{array}$ & 0.06 & $\begin{array}{l}\text { Common } \\
\text { Grackle }\end{array}$ & 0.50 & Blue Jay & 0.17 & $\begin{array}{l}\text { European } \\
\text { Starling }\end{array}$ & 0.68 \\
\hline \multirow[t]{5}{*}{ PNW } & $\begin{array}{l}\text { House } \\
\text { Finch }\end{array}$ & 4.76 & $\begin{array}{l}\text { American } \\
\text { Robin }\end{array}$ & 1.84 & $\begin{array}{l}\text { House } \\
\text { Finch }\end{array}$ & 1.33 & $\begin{array}{l}\text { American } \\
\text { Robin }\end{array}$ & 5.33 \\
\hline & $\begin{array}{l}\text { American } \\
\text { Goldfinch }\end{array}$ & 3.87 & $\begin{array}{l}\text { American } \\
\text { Goldfinch }\end{array}$ & 0.25 & $\begin{array}{l}\text { American } \\
\text { Robin }\end{array}$ & 0.56 & $\begin{array}{l}\text { Cedar } \\
\text { Waxwing }\end{array}$ & 0.76 \\
\hline & $\begin{array}{l}\text { American } \\
\text { Robin }\end{array}$ & 3.73 & $\begin{array}{l}\text { Dark-eyed } \\
\text { Junco }\end{array}$ & 0.25 & $\begin{array}{l}\text { Dark-eyed } \\
\text { Junco }\end{array}$ & 0.41 & House Finch & 0.70 \\
\hline & $\begin{array}{l}\text { Brewer's } \\
\text { Blackbird }\end{array}$ & 1.33 & $\begin{array}{l}\text { White- } \\
\text { crowned } \\
\text { Sparrow }\end{array}$ & 0.18 & $\begin{array}{l}\text { Yellow- } \\
\text { rumped } \\
\text { Warbler }\end{array}$ & 0.36 & $\begin{array}{l}\text { Western } \\
\text { Kingbird }\end{array}$ & 0.60 \\
\hline & $\begin{array}{l}\text { European } \\
\text { Starling }\end{array}$ & 1.16 & $\begin{array}{l}\text { House } \\
\text { Finch }\end{array}$ & 0.14 & $\begin{array}{l}\text { Northern } \\
\text { Flicker }\end{array}$ & 0.10 & $\begin{array}{l}\text { American } \\
\text { Goldfinch }\end{array}$ & 0.57 \\
\hline
\end{tabular}

${ }^{\text {a }} \mathrm{MI}=$ Michigan, $\mathrm{NY}=$ New York, PNW = Pacific Northwest

${ }^{\mathrm{b}}$ Birds that are important fruit consumers for each region and crop are shown in bold; this classification was based on the bird species being both frequently sighted and recorded as a high consumer of fruit (see Methods). 


\subsection{Model Results}

Our results for the fruit-eating bird models show that abundance varied across regions in all crops except grapes; the $95 \%$ credible interval $(\mathrm{Cl})$ for parameter values for region in each of the crop models with the exception of grapes did not include zero. Land-cover heterogeneity did not significantly influence fruit-eating bird abundance in any of the crop models, as the $95 \% \mathrm{Cl}$ for the heterogeneity parameter in each model included zero. Our separate models for the effectiveness of bird management showed that with the exception of blueberries, bird management did not significantly reduce bird abundance.

\subsubsection{Abundance Estimates}

Abundance estimates from the n-mixture models for fruit-eating birds and robins varied among crops (Figure 1). For all fruit-eating birds, estimated mean abundance was highest in apples in the Pacific Northwest in 2013, and lowest in apples in Michigan in 2012.

Abundance estimates did not differ across the three regions in the grape model. For blueberries, the highest mean abundances were in Michigan for both 2012 and 2013. Sweet cherries showed consistently high abundances of fruit-eating birds across all 3 regions, although they did differ among regions and years. Pacific Northwest sweet cherries had the highest means for bird abundance for both years of the study, compared to New York and Michigan. 

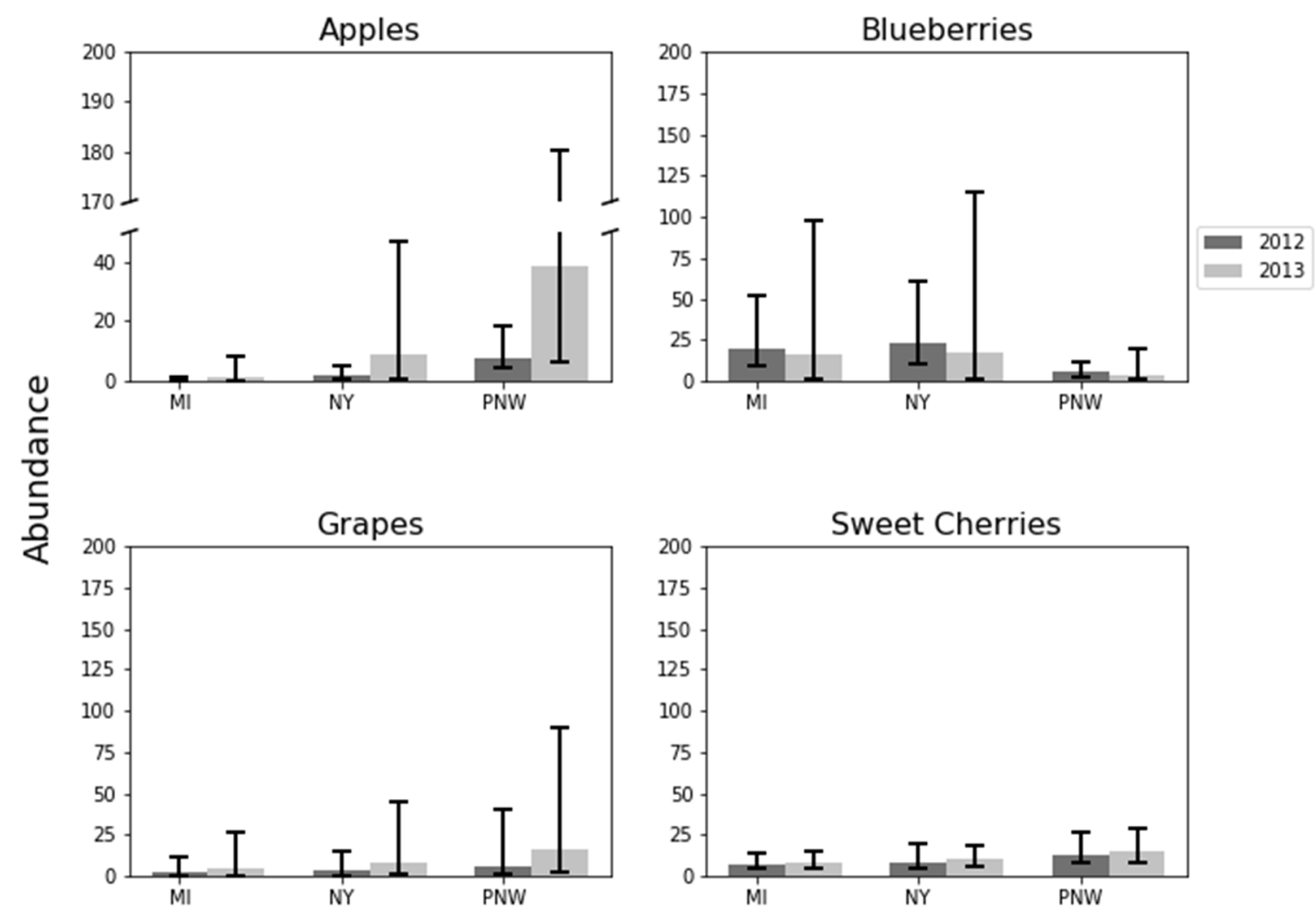

Fig. 1. Abundance estimates from the fruit-eating bird models, shown as mean number of birds per point count area, comparing within crops among regions in Michigan (MI), New York (NY), and the Pacific Northwest (PNW) during 2012 and 2013. Error bars represent $95 \%$ credible intervals.

\section{Discussion and Conclusion}

Waxwings were designated as important fruit consumers in Michigan blueberries, and sweet cherries in New York and the Pacific Northwest. This pattern is surprising, given that waxwings are common in Eastern regions of the United States, and have been recorded as frequent fruit consumers. We expected them to be important fruit consumers in all small-fruit crops, particularly in the Eastern study regions (Lindell et al., 2012a; Rodewald, 2015). House finches were important in blueberries, apples, and sweet cherries only in the Pacific 
Northwest; they are more abundant in western regions of the United States than in the east (Rodewald, 2015). Robins were important fruit consumers in sweet cherries and blueberries for all regions, in addition to grapes in the Pacific Northwest. American goldfinches were found to be important in blueberries in both Michigan and the Pacific Northwest. Relatively few bird species were deemed important fruit consumers in grapes; this does not support our prediction that the smaller fruits in our study would have both high abundances and numbers of fruit-eating species and runs counter to literature showing high bird damage in grape vineyards (Stevenson and Virgo, 1971; Somers and Morris, 2002a). We were also surprised by the relatively low number of starlings detected, especially in grapes, as starlings have been shown to cause damage to grapes (Somers and Morris, 2002b).

Land-cover heterogeneity was not a significant influence on fruit-eating bird abundance, in contrast to the results of other studies that have shown that increases in land-cover heterogeneity lead to increased bird abundance in agricultural fields (Guerrero et al., 2012). There could be characteristics of our study system that masked any effects land-cover heterogeneity had on bird abundance. Bird damage in Pacific Northwest apples is low (Lindell et al., 2016), even though abundance estimates for fruit-eating birds in Pacific Northwest apples from this study were higher than for other regions. The Pacific Northwest had much larger orchard sizes than the other two regions; this could lead to damage being 'diluted' in the larger orchards, despite higher bird abundances. This was demonstrated in sweet cherries where larger orchards exhibited lower overall rates of bird damage (Leigh, 2015).

Results from this study have important implications for fruit growers, who can have misconceptions about which species are problematic in their crops. A study by Anderson et al., (2013) conducted surveys of fruit growers in the same regions and crops as our study, asking them to identify bird species responsible for fruit damage. Robins were correctly identified as damaging to fruit in many crops; however, waxwings were never listed as problematic, even though we found them to be important in blueberries and sweet cherries 
(Anderson et al., 2013). Additionally, starlings were listed as problematic in every fruit category in the surveys (Anderson et al., 2013), yet were only ranked as important fruit consumers in the present study in Pacific Northwest blueberries.

These misconceptions can lead to missed opportunities to implement effective speciesspecific management strategies. One such bird-management technique is the use of unmanned aircraft systems (drones). Preliminary information suggests that drones could be used in areas predated by larger fruit-eating birds, and birds that are not strongly territorial (Mulero-Pázmány et al., 2017). This could include birds outside of their breeding season, or species such as waxwings that typically defend a small area around a colonial nest (Tracey et al., 2007; Rodewald, 2015). Drones have also shown promise against flocks (MuleroPázmány et al., 2017), which could be beneficial in crops that often host large flocks of fruiteating birds in the fall, such as starlings in New York blueberries. Species-targeted strategies such as decoy trapping can be effective against some species such as starlings (Conover and Dolbeer, 2007).

Our study found that bird management measures did not decrease bird abundance in any crop except blueberries. Another study in the same crop systems found that bird deterrents did not reduce bird damage (Elser et al., under review). A study in grape and blueberry crops found that inflatable tubemen may be effective deterrents, but only in contexts, and that methyl anthranilate sprays are ineffective (Lindell et al., 2018). Many scaring techniques are effective at first, but lose effectiveness due to habituation (Baxter and Robinson, 2007). Integrated pest management (IPM), which is a combination of pest management practices, is likely the optimal way to deter pest bird populations. IPM can incorporate techniques that have shown to be effective on certain species or in particular situations. For example, it has been shown that 'sonic nets' can disrupt starlings' ability to communicate, and therefore displaces them from an area (Swaddle et al., 2016). In parts of the U.S. where American kestrels breed, putting up kestrel nest boxes in cherry orchards has been shown to greatly reduce the number of fruit-eating birds (Shave et al., 2018). 
Dolbeer (1990) suggested IPM as a solution to red-winged blackbird (Agelaius phoeniceus, hereafter blackbirds) corn consumption. Blackbirds only feed on corn for a short period during the year; the rest of the time they consume insects. Dolbeer (1990) suggested that a combination of planting different cultivars, harvesting a few days earlier, and targeted scaring techniques during a short critical period can mitigate damage caused by blackbirds in corn fields, while also using the pest control services they provide.

In our study there are several important fruit consumers that could provide beneficial ecosystem services. Robins spend a good deal of time foraging on fruit that has fallen to the ground (Eaton, 2016) which may remove fruit that would otherwise serve as a reservoir for pests and diseases. Other preliminary work suggests that birds foraging on the ground may remove insect crop pests directly (Lindell et al., unpubl. data). Juvenile robins have a higher proportion of fruit in their diet than adults (Rodewald, 2015) - targeted scaring of juveniles could prevent crop loss, while also allowing them to provide pest control services during other parts of the year. The Baltimore oriole, found to be an important fruit consumer in New York blueberries, is another omnivorous species that could be potentially be beneficial to crops during parts of its life cycle. Baltimore orioles switch from an insect-based diet during the summer to a fruit-rich diet in the fall (Rodewald, 2015). Planting earlier ripening cultivars of blueberries could lessen the extent of fruit consumption caused by this species, while still allowing them to consume insects during the summer. IPM strategies that use speciesspecific ecology have the potential to mitigate crop damage, while also harnessing potential ecosystem services.

As a final note, we suggest that more research be conducted on the effectiveness of point counts as a sampling method for flocking species. Several results that we found surprising may be due to point counts not capturing large flocks, as flocks move around frequently and often scare when approached (Melissa Hannay, Michigan State University, personal observation). This could be one cause of the lack of starlings seen in our study; starlings 
tend to gather in large flocks in the fall, when some fruits such as certain grape cultivars are harvested (Rodewald, 2015).

\section{Acknowledgements}

This work was supported by the Specialty Crop Research Initiative of USDA/NIFA (Grant number: 2011-51181-30860), the Cherry Marketing Institute, the Michigan Apple Committee, Environment Canada Science Horizons, and the Ecology, Evolutionary Biology, and Behavior Program at Michigan State University. We sincerely thank the many fruit growers that worked with us. We would also like to thank Shayna L. Wieferich and Heidi M. Henrichs for their work. We would also like to thank both reviewers for their helpful feedback. Those who funded this study were not involved with study design, data collection, writing of this report, or decision to submit the article for publication.

\section{References}

Anderson, A., Lindell, C.A., Moxcey, K.M., Siemer, W.F., Linz, G.M., Curtis, P.D., Carroll, J.E., Burrows, C.L., Boulanger, J.R., Steensma, K.M. M., Shwiff, S.A., 2013. Bird damage to select fruit crops: the cost of damage and the benefits of control in five states. Crop Prot. 52, 103-109.

Avery, M.L., Nelson, J.W., Cone, M.A., 1992. Survey of bird damage to blueberries in North America. Proc. East. Wildl. Damage Control Conf. 5, 105-110.

Baxter, A.T., Robinson, A.P., 2007. A comparison of scavenging bird deterrence techniques at UK landfill sites. Int. J. Pest. Manage. 53(4), 347-356.

Boudreau, G., 1972. Factors related to bird depredations in vineyards. Am. J. Enology Vitic. $23,50-53$. 
Conover, M.R., Dolbeer, R.A., 2007. Use of decoy traps to protect blueberries from juvenile European starlings. Hum. Wildl. Confl. 1, 265-270.

Dolbeer, R.A., 1990. Ornithology and integrated pest management; red-winged blackbirds Agelaius phoeniceus and corn. Ibis 132, 309-322.

Dolbeer, R.A., Woronecki, P.P., Seamans, T.W., 1995. Ranking and evaluation of field corn hybrids for resistance to blackbird damage. Crop Prot. 14 (5), 399-403.

Eaton, R. A., 2016. Influences of diet, spatial scale, and sociality on avian foraging behavior and habitat use in cultivated sweet cherry orchards and the resulting implications for management [dissertation]. East Lansing: Michigan State University.

Elser, J.L., Lindell, C.A., Steensma, K.M.M., Curtis, P.D., Leigh, D.K., Siemer, W.F., Boulanger, J.R., Shwiff, S.A. Measuring bird damage to three fruit crops: a comparison of grower and field estimates. Crop Prot. Under review.

Fletcher, R.J., Koford, R.R., 2002. Habitat and landscape associations of breeding birds in native and restored grasslands. J. Wildlife Manage. 66 (4), 1011-1022.

Guerrero, I., Morales, M.B., Oñate, J.J., Geiger, F., Berendse, F., de Snoo, G., Eggers, S., Pärt, T., Bengtsson, J., Clement, L.W., Weisser, W.W., Olszewski, A., Ceryngier, P., Hawro, V., Liira, J., Aavik, T., Fischer, C., Flohre, A., Thies, C., and Tscharntke, T., 2012. Response of ground-nesting farmland birds to agricultural intensification across Europe: landscape and field level management factors. Biol. Conserv. 152, 74-80.

Johnson, D., Guthery, F., Koerth, N.E., 1989. Grackle damage to grapefruit in the lower Rio Grande Valley. Wildlife Soc. B. 17, 46-50.

Kéry, M., 2010. Introduction to WinBUGS for Ecologists: Bayesian approach to regression, ANOVA, mixed models and related analyses. Academic Press, Orlando, FL.

Kéry, M., Schaub, M., 2012. Bayesian population analysis using WinBUGS, a hierarchical perspective. Academic Press, Waltham, Massachusetts. 
Leigh, Deanna K., 2015. The effect of American kestrels on deterrence of bird damage to Pacific Northwest sweet cherries [dissertation]. WWU Graduate School Collection, 457. https://cedar.wwu.edu/wwuet/457 (accessed 05.09.2018).

Lindell, C.A., Eaton, R.A., Lizotte, E.M., Rothwell, N.L., 2012a. Bird consumption of sweet and tart cherries. Hum.-Wildl. Interact. 6 (2), 283-290.

Lindell, C.A., Shwiff, S.A., Howard, P.H., 2012b. Bird management in fruit crops: how we make progress. Proc. 25th Vertebr. Pest Conf. 235-239. Davis, CA: University of California. Lindell, C.A., Steensma, K.M., Curtis, P.D., Boulanger, J.R., Carroll, J.E., Burrows, C., Lusch, D.P., Rothwell, N.L., Wieferich, S.L., Henrichs, H.M., Leigh, D.K., Eaton, R.A., Linz, G.M., 2016. Proportions of bird damage in tree fruits are higher in low-fruit-abundance contexts. Crop Prot. 90, 40-48.

Lindell, C.A., Hannay, M.B., Hawes, B.C., 2018. Bird management in blueberries and grapes. Agronomy. 8 (12), 295.

Linz, G.M., Peer, B.D., Homan, J.H., Wimberly, R.L., Bergman, D.L., 2002. Has an integrated pest management approach reduced blackbird damage to sunflower? In: Clark, L., Hone, J., Shivik, J.S., Watkins, R.W., VerCauteren, K.C., Yoder, J.K. (Eds.), Human Conflicts With Wildlife: Economic Considerations. Proceedings of the 3rd NWRC Special Symposium of the National Wildlife Research Center, 1-3 August 2000, Fort Collins, Colorado, USA, pp. $132-137$.

Luck, G.W., Hunt, K., Carter, A., 2015. The species and functional diversity of birds in almond orchards, apple orchards, vineyards and eucalypt woodlots. Emu 115, 99-109.

Morrison, E.B., Lindell, C.A., Holl, K.D., Zahawi, R.A., 2009. Patch size effects on avian foraging behaviour: implications for tropical forest restoration design. J. Appl. Ecol. 47, 130138. 
Mörtberg, U.M., 2001. Resident bird species in urban forest remnants; landscape and habitat perspectives. Landscape Ecol. 16 (3), 193-203.

Mulero-Pázmány, M., Jenni-Eiermann, S., Strebel, N., Sattler, T., Negro, J.J., Tablado, Z., 2017. Unmanned aircraft systems as a new source of disturbance for wildlife: a systematic review. PLOS One 12 (6), 1-14.

National Agricultural Imagery Program (NAIP) Information Sheet, 2013. United States Department of Agriculture Farm Service Agency. https://www.fsa.usda.gov/Internet/FSA File/naip info sheet 2013.pdf (accessed 01.07.2018).

Nichols, J.D., Hines, J.E., Sauer, J.R., Fallon, F.W., Fallon, J.E., Heglund, P.J., 2000. A double-observer approach for estimating detection probability and abundance from point counts. Auk 117 (2), 393-408.

Pearson, S.M., 1993. The spatial extent and relative influence of landscape-level factors on wintering bird populations. Landscape Ecol. 8 (1), 3-18.

Ralph, C.J., Sauer, J.R., Droege, S., 1995. Monitoring bird populations by point counts. Gen. Tech. Rep. PSW-GTR-149. Albany, CA: U.S. Department of Agriculture, Forest Service, Pacific Southwest Research Station.

Rodewald, P., 2015. The Birds of North America Online. Cornell Laboratory of Ornithology, Ithaca, NY. http://bna.birds.cornell.edu/BNA/ (accessed 01.01.18)

Royle, A.J., Nichols, J.D., 2003. Estimating abundance from repeated presence-absence data or point counts. Ecol. 84(3), 777-790.

Royle, A.J., 2004. N-mixture models for estimating population size from spatially replicated counts. Biometrics 60, 108-115.

Saïd, S., Servanty, S., 2005. The influence of landscape structure on female roe deer homerange size. Landscape Ecol. 20 (8), 1003-1012. 
Sauer, J.R., Niven, D.K., Hines, J.E., Ziolkowski, D.J., Pardieck Jr. K., Fallon, J.E., Link, W., 2017. The North American breeding bird survey, results and analysis 1966-2015. Version 2.07.2017. USGS Patuxent Wildlife Research Center, Laurel, MD.

Shave, M.E., Shwiff, S.A., Elser, J.L., Lindell, C.A., 2018. Falcons using orchard nest boxes reduce fruit-eating bird abundances and provide economic benefits for a fruit- growing region. J. Appl. Ecol. 1-10. DOI:10.1111/1365-2664.13172

Somers, C.M., Morris, R.D., 2002a. Birds and wine grapes: foraging activity causes smallscale damage patterns in single vineyards. J. Appl. Ecol. 39 (3), 511- 523.

Steensma, K., Lindell, C., Leigh, D., Burrows, C., Wieferich, S., Zwamborn, E., 2016. Bird damage to fruit crops: a comparison of several deterrent techniques. Proc. Vert. Pest Conf. 27, 196-203.

Stevenson, B., Virgo, B., 1971. Damage by robins and starlings to grapes in Ontario. Can. J. Plant Sci. 51, 201-210.

Su, Y. S., Yajima, M., 2012. R2jags: A package for running jags from R. https://CRAN.Rproject.org/package=R2jags (accessed 01.01.14).

Swaddle, J.P., Moseley, D.L., Hinders, M.K., Smith, E.P. A sonic net excludes birds from an airfield: implications for reducing bird strike and crop losses. Ecol. Appl. 26(2), 339-345.

Tobin, M.E., Dolbeer, R.A., Woronecki, P., 1989. Bird damage to apples in the mid- Hudson Valley of New York. Hortic. Sci. 24, 859.

Tracey, J., Bomford, M., Hart, Q., Saunders, G., Sinclair, R., 2007. Managing bird damage to fruit and other horticultural crops. Bureau of Rural Sciences, Canberra.

https://www.dpi.nsw.gov.au/ data/assets/pdf file/0005/193739/managing bird damagefull-version.pdf (accessed 22.04.2014).

United States Department of Agriculture National Agricultural Statistics Service, 2016. Noncitrus fruits and nuts 2015 summary. 
http://usda.mannlib.cornell.edu/usda/nass/NoncFruiNu//2010s/2016/NoncFruiNu-07-06-

2016.pdf (accessed 28.09.2016).

Witmer, M., Soest, P. J. V., 1998. Contrasting digestive strategies of fruit-eating birds. Funct.

Ecol. 12, 728-741.

Young, H., 1956. Territorial activities of the American robin Turdus Migratorius. Ibis 98 (3), 448-452. 